\title{
A global infrageneric classification system for the genus Crotalaria (Leguminosae) based on molecular and morphological evidence
}

\author{
Marianne M. le Roux, James S. Boatwright and Ben-Erik van Wyk
}

\begin{abstract}
Crotalaria is a large genus of 702 species with its centre of diversity in tropical Africa and Madagascar and secondary radiations in other parts of the world. The current infrageneric classification system is based on morphological and morphomet- ric studies of the African taxa only and is here re-evaluated using a phylogenetic approach. DNA sequences derived from the nuclear ITS and the plastid matK, $p s b A-\operatorname{trn} H$ and rbcLa markers were analyzed using parsimony and model-based (Bayesian) approaches. The resultant molecular phylogeny allowed for a new interpretation of diagnostically important morphological characters, including specialisations of the calyx, keel, standard petal and style, which are variously convergent in several unrelated infrageneric groups. Of particular interest is the congruence between the new phylogeny and the distribution of stand- ard petal callosity types. A sectional classification system for the entire genus is proposed for the first time. The new system that is formalised here comprises eleven sections: Amphitrichae, Calycinae, Crotalaria, Geniculatae, Glaucae, Grandiflorae, Hedriocarpae, Incanae, Schizostigma, Borealigeniculatae and Stipulosae. Sectional limits of the Geniculatae, Calycinae and Crotalaria are modified. The subsections Stipulosae, Glaucae and Incanae are raised to sectional level, while some groups previously recognized as subsections are abandoned due to non-monophyly (subsections Chrysocalycinae, Hedriocarpae, Macrostachyae and Tetralobocalyx). Two new sections are recognized, Amphitrichae and Borealigeniculatae.
\end{abstract}

\section{Introduction}

The large genus Crotalaria L. comprises 702 species and is widely distributed, especially in the Southern Hemisphere (Van Wyk, 2005; Jianqiang \& al., 2010; Le Roux \& al., subm.). It has its primary centre of species diversity in tropical and subtropical Africa and Madagascar (Polhill, 1982; Van Wyk, 2005; Flores \& al., 2006), where some 543 species occur, and secondary radiations in temperate Asia, tropical Asia and Australasia with 159 species, South America (especially Brazil) with 64 species and North America (Mexico and the southern parts of the United States of America) with 34 species (Le Roux \& al., subm.; Flores \& al., 2006; Pandey \& al., 2010). These figures include the total number of species in each individual region, i.e., species that occur in more than one region are included in each region. 
The genus is part of the largely African tribe Crotalarieae, and together with Bolusia Benth. and Euchlora Eckl. \& Zeyh. sister (100\% BS, PP 1.0; Boatwright \& al., 2008a) to the re- mainder of the tribe (Polhill, 1976, 1982; Van Wyk, 1991, 2003, 2005; Van Wyk \& Schutte, 1989, 1995; Boatwright \& al., 2008a, 2011). Crotalaria is easily recognized by a unique combination of characters, namely a rostrate keel, highly inflated fruit, a hairy style, a $5^{+} 5_{\text {-anther configuration, }}$ paired callosities on the stand- ard petal and the presence of macrocyclic pyrrolizidine alkaloids (Polhill, 1982; Van Wyk \& Verdoorn, 1990; Van Wyk, 2005). Bolusia differs from Crotalaria in having a helically coiled keel with a single callosity restricted to the standard petal blade (Van Wyk \& al., 2010; Le Roux \& Van Wyk, 2012). Euchlora lacks standard petal callosities and has an obtuse to somewhat rostrate keel beak (Le Roux \& Van Wyk, 2012).

Polhill (1968) re-evaluated the infrageneric classification system following previous work by Bentham (1843), Harvey (1862), Baker (1914), Verdoorn (1928), Wilczek (1953a, b), Hepper (1958), Milne-Redhead (1961, and unpub.), Torre (1962) and Schreiber (1970). He recognized eleven sections and eight subsections in Africa and Madagascar, mainly derived from floral and fruit characters. Morphometric studies were also conducted by Bisby (1970, 1973), who wanted to illustrate the application and potential value of numerical taxonomic meth-ods and used Crotalaria as model genus. Bisby (1973) noted the difficulty of classifying Crotalaria into natural groups of work- able sizes, due to the large number of species and high levels of interspecific variation potentially caused by reticulation. 


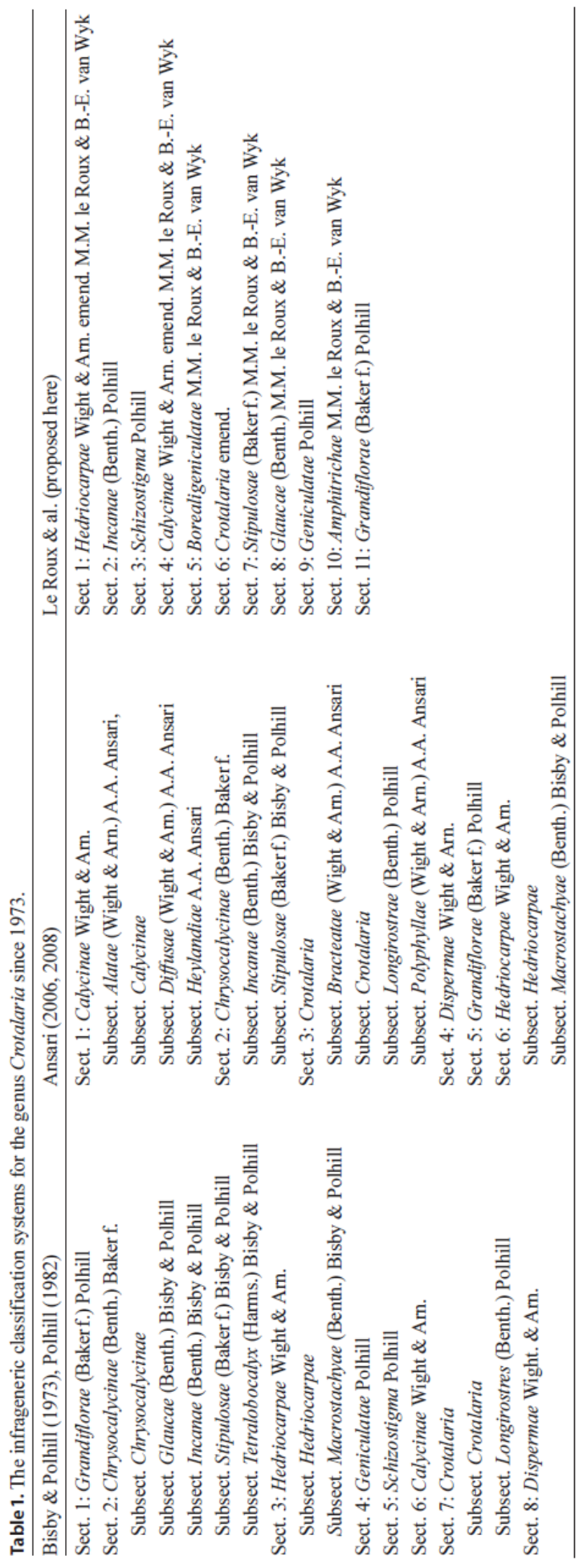

In 1973, Polhill \& Bisby combined their datasets which resulted in small changes to the system proposed by Polhill (1968), with eight sections and nine subsections (listed in Table 1) recognized in the revision of the African and Madagascan species (Polhill, 1982). The new circumscriptions were mainly based on floral characters. 
Polhill distinguished between two groups in Crotalaria, derived from the distribution of callosities associated with the standard petal. They are referred to by Polhill (1982) as the "unspecialised group" which includes sections Grandiflorae, Chrysocalycinae and Hedriocarpae while the so-called "spe- cialised group" includes sections Calycinae, Crotalaria and Dispermae and two "intermediate sections", Geniculatae and Schizostigma (Bisby \& Polhill, 1973). The term "specialised" refers to those taxa that exhibit a whole suite of morphological adaptations that are related to an increasing level of complex- ity in the pollination syndrome. Unspecialised floral charac- ters include callosities present on the standard petal blade and claw (Fig. 1A1), a rounded keel with the curvature at about or below the middle (Fig. 1B1, B2), a straight keel beak (rarely circumflexed or twisted in older flowers) and a rounded style (Fig. ${ }_{1 F}$ ), usually with one line of trichomes (Fig. $1 \mathrm{~F} 1, \mathrm{~F} 4$ ). Specialised floral characters include callosities restricted to the blade (Fig. 1A2-A4), a rounded, subangled or angled keel (Fig. 1B5, B6) with the curvature rarely at about the middle, usu- ally below the middle or angled in the lower third, a twisted keel beak (except in section Geniculatae) and a rounded (Fig. $1 \mathrm{~F} 7$ ) or geniculate (Fig. 1F8) style with two lines of trichomes (Fig. 1F2, F5) (or less frequently one line; Le Roux \& Van Wyk, 2012).

Ansari (2006, 2008) published a revision of the infrage- neric classification system of Crotalaria to accommodate the Indian species. Six of the eight sections as recognized by Polhill (1982) (Table 1) are present in India. Ansari created four new subsections in section Calycinae and two new subsections in section Crotalaria using floral and vegetative characters, but he did not consider the total range of variation of these characters across the genus (extra-Indian species). Apart from studies at the generic level (Boatwright \& al., 2008a), no molecular systematic studies of the large and unwieldy genus Crotalaria have yet been attempted. Therefore this study was aimed at present- ing a first molecular phylogeny for the genus based on nrDNA internal transcribed spacer (ITS) sequences, along with plas- tid matK, $p s b A$-trnH and rbcLa sequences. The phylogenetic approach is used to identify monophyletic groups, to assess the congruence between morphological and sequence-based patterns and to evaluate the current hypotheses of infrageneric relationships based on regional Floras (Polhill, 1982; Ansari, 2006, 2008). The ultimate aim of our study was not to merely explore monophyly, but to propose, for the first time, a practical and workable global infrageneric classification system, based on careful consideration of the main patterns of character state distributions in all species from all continents. We were also interested in exploring new ways of interpreting the evolu- tion of salient morphological features of the flowers (Le Roux \& Van Wyk, 2012) that were previously used by Polhill (1982) as diagnostic characters to define sections and subsections. 

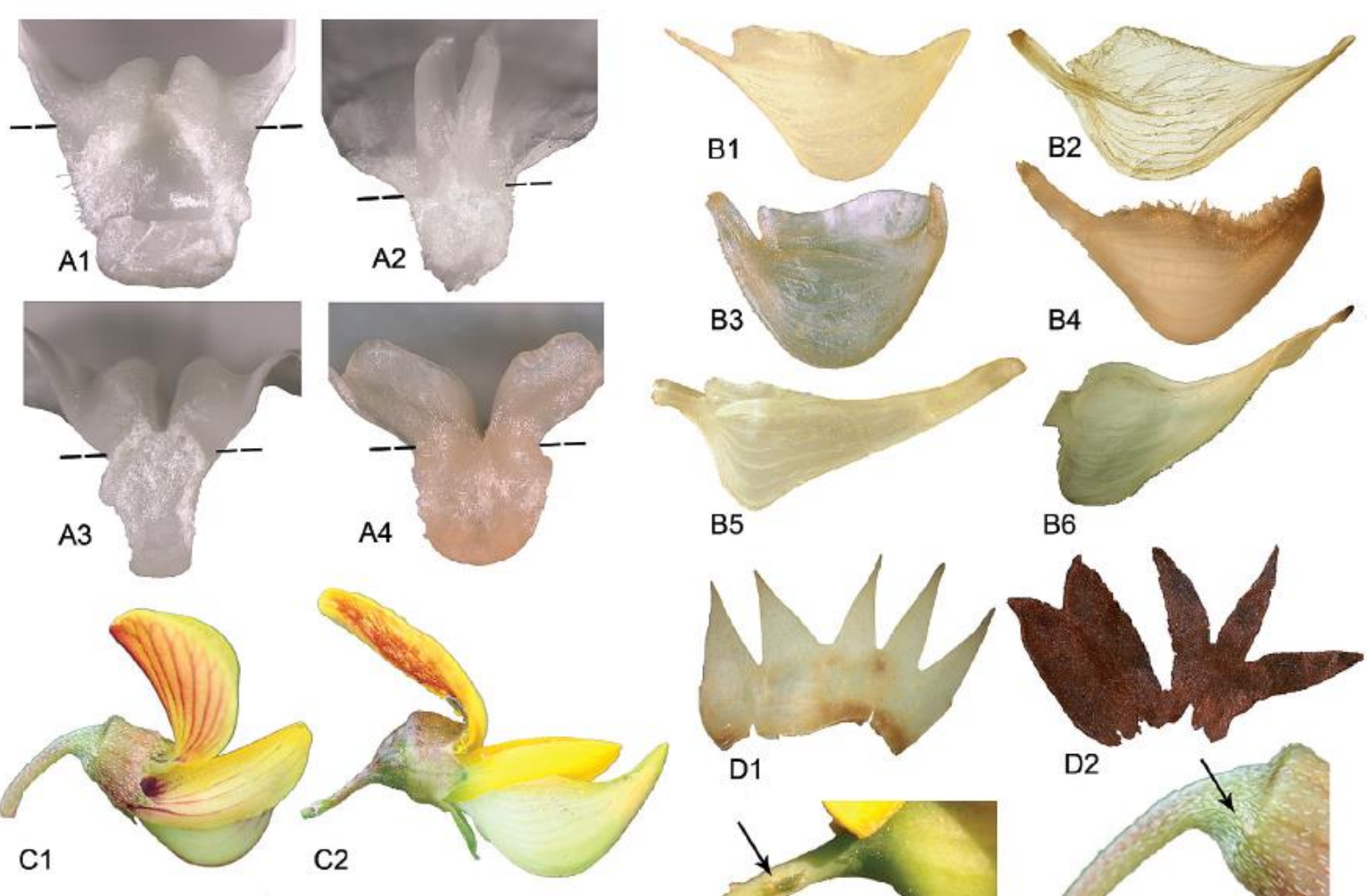

B5

B6

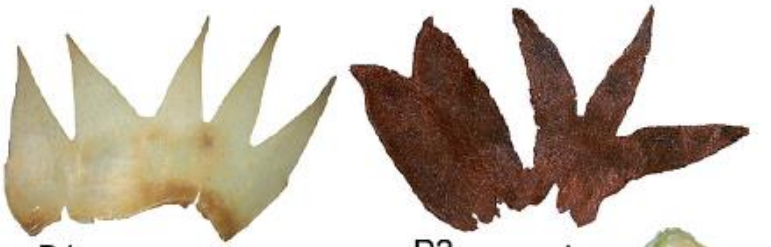

D1

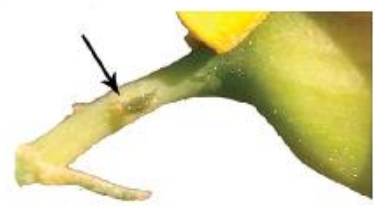

E1

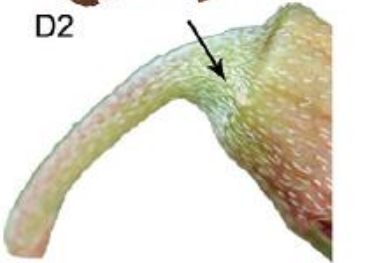

E2

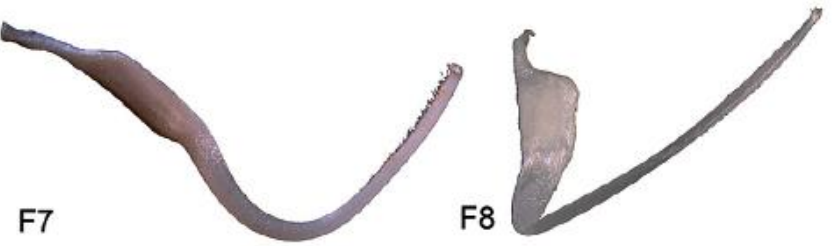

F2

F3

F7

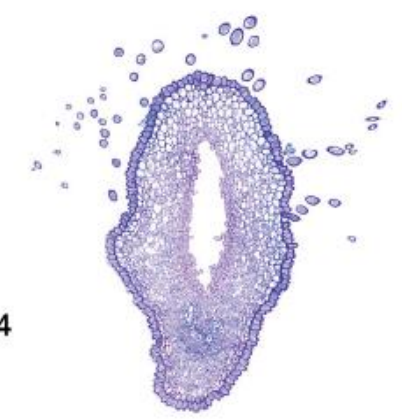

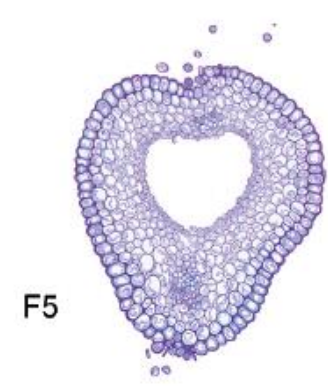

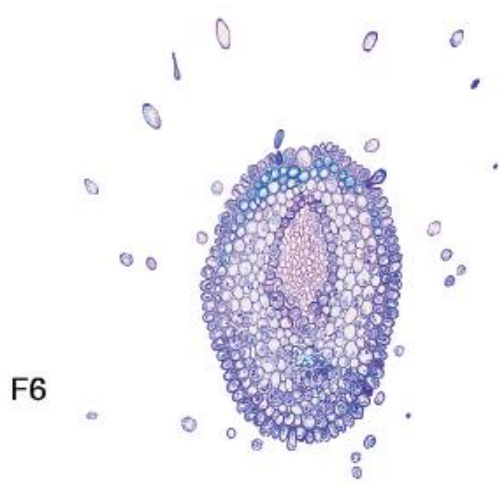

Fig. 1. Diagnostic floral characters and character states in Crotalaria. A, shape and distribution of callosities on the standard petal; B, shape and vestiture of the keel petals and shape of the beaks; C, D, shape of the calyx tubes and lobes; $\mathbf{E}$, position of the bracteoles on the pedicel; $\mathbf{F}$, vestiture and shape of styles. A1, ridge callosities present on the blade and claw; A2, columnar callosities present on the blade only; $\mathbf{A} 3$, disc callosities present on the blade only; A4, lamelliform callosities present on the blade only (the dotted line indicates the division between the standard petal blade and claw); B1, a rounded keel with an untwisted beak; B2, a sub-angled keel with a twisted beak; B3, a rounded keel with a circumflexed beak; B4, a rounded keel with an untwisted beak, but with lanate-pilose trichomes on the upper edge of the keel; B5, angled keel with an untwisted beak; B6, angled keel with a twisted beak; C1, truncate calyx tube; C2, campanulate calyx tube; D1, sub-equally lobed calyx; D2, bilabiate calyx; E1, bracteoles inserted on the pedicel; E2, bracteoles inserted on the calyx; F1, F4, style in side view and cross section, with trichomes in a single line along the upper edge; F2, F5, style in side view and cross section, with trichomes in two lines along the upper and lower edges; F3, F6, style in side view and cross section, with dispersed trichomes all around the style; $\mathbf{F 7}$, rounded style; and $\mathbf{F 8}$, geniculate style. 


\section{Materials and methods}

Taxon sampling. - Fieldwork was conducted in Botswana, Ethiopia, Namibia and South Africa to collect silica-dried leaf material for DNA sequencing. Additional samples were either obtained as gifts or were taken from herbarium specimens to include representative samples of all sections in the current infrageneric classification system from all continents. Voucher specimen information is listed in Appendix S1 along with au- thor citations for all taxa and these are not repeated elsewhere. A sister relationship was shown between Bolusia and Crota- laria (Polhill, 1976, 1982), which was recently confirmed by molecular studies (92\% BS, PP 1.00; Boatwright \& al., 2008a, 2011). Furthermore, the latter studies indicated that Crotalaria, Bolusia and the monotypic genus Euchlora form a strong clade (99\% BS, PP 1.00), therefore both Euchlora and Bolusia were chosen as outgroups in this study (Boatwright \& al., 2008a).

DNA extraction, amplification and sequencing. - The majority of DNA extractions were carried out at the Molecu- lar Systematics Laboratory at the University of Johannesburg (UJ), South Africa. Two extraction methods were used: (1) silica-dried leaf material (0.1-0.3 g) was extracted using the $2 \times$ hexadecyltrimethylammonium bromide (CTAB) method (Doyle \& Doyle, 1987) and purified using QIAquick silica col- umns (Qiagen Inc., Hilden, Germany); (2) leaf material sampled from herbarium specimens $(0.008-0.020 \mathrm{~g})$ was extracted and purified with a DNeasy plant minikit (Qiagen Inc.) following the manufacturer's protocol. A total of 15 DNA samples were obtained from Kew Herbarium (K), and were extracted by the Jodrell Laboratory, U.K. The DNA regions were amplified using polymerase chain reactions (PCR) in $25 \mu \mathrm{l}$ reactions, following Boatwright \& al. (2008a), but with 10-40 ng DNA template, $1 \mu$ l $0.004 \%$ bovine serum albumin (BSA) and $1 \%$ dimethyl sulfoxide (DMSO) in the PCR reactions for amplifica- tion of ITS. Successfully amplified PCR products were purified using either the QIAquick PCR purification kit (Qiagen Inc.), according to the manufacturer's instructions, or the ExoSAP protocol of Werle \& al. (1994) using 5 units of Exonuclease I and 0.5 units of Shrimp Alkaline Phosphatase. Four DNA re- gions were amplified: nuclear ribosomal ITS (primers of White \& al., 1990 and Sun \& al., 1994); barcoding matK (standard barcoding primers of KiJoong Kim: 3F_KIM f: CGT ACA GTA CTT TTG TGT TTA CGA G; 1R_KIM r: ACC CAG TCC ATC TGG AAA TCT TGG TTC); barcoding rbcLa (standard barcoding primers of Kress \& Erickson, 2007) and; psbA-trnH (primers of Sang \& al., 1997).

The ITS region was chosen because previous studies by Boatwright \& al. (2008a, 2011) have shown that it provides robust resolution at higher taxonomic levels for the tribe Cro- talarieae. Three additional regions were chosen, one that is phylogenetically conservative ( $r b c L a$ ) and two that are evolv- ing more rapidly, matK and psbA-trnH. These regions have been under consideration as DNA barcoding markers and have shown to be informative (Kress \& Erickson, 2007; Edwards \& al., 2008; Lahaye \& al., 2008; Kress \& al., 2009).

Sequences were completed for the barcoding plastid gene regions rbcLa and matK at the UJ lab as well as the Canadian Centre for DNA Barcoding (University of Guelph, Canada; see Appendix S1) using standard barcoding PCR and cycle sequencing programs and loaded onto the Barcode of Life Data System (BOLD; Ratnasingham \& Hebert, 2007). The ITS and psbA-trnH

\section{http://repository.uwc.ac.za}


regions were solely amplified at UJ using PCR and cycle sequencing programs as described by Boatwright \& al. (2008b) and Downie \& Katz-Downie (1996) in problematic cases (where degraded DNA was extracted from old herbarium specimens and as a result were difficult to amplify).

Sequence alignment and phylogenetic analyses. - Complementary sequences were assembled and edited in Sequencher v.4 (Gene Codes Corporation), aligned manually in PAUP* v.4.ob10 (Swofford, 2002) and in MEGA v.4 (Tamura \& al., 2007). No problematic areas were encountered during the alignment of the datasets and particular care was taken in the case of $p s b A$-trn $H$ following reports of frequent inver- sions in the region that might affect estimation of relationships (Bain \& Jansen, 2006; Whitlock \& al., 2010). Insertions and deletions were coded as missing data and did not contribute to the analyses. The DNA sequences have been submitted to GenBank (accession numbers listed in Appendix S1) and the datasets to TreeBASE (submission number 12059).

Parsimony analysis (MP; Fitch, 1971) and Bayesian Infer- ence (BI) were used to analyse the data. MP analyses were per- formed in PAUP* for the four individual gene matrices using a heuristic search with 1000 random sequence additions and holding 10 trees per replicate with tree bisection-reconnection (TBR) branch swapping and the MULTREES options in effect. Delayed transformation character optimization (DELTRAN) was used to illustrate branch lengths. Internal support was determined using bootstrap analysis (Felsenstein, 1985) with 1000 replicates holding 10 trees per replicate, TBR branch swapping and MULTREES options in effect. Bootstrap values were evaluated according to the following scale: $50 \%-74 \%$, low; $75 \%-$ $84 \%$, moderate; $85 \%-100 \%$, strong. The bootstrap consensus trees for each of the four individual datasets were evaluated for congruence. We relied only on visual inspection of the bootstrap consensus trees and no statistical analysis were done due to the unreliability of tests such as the length incon- gruence test (ILD; Farris \& al., 1995) shown in previous stud- ies (Reeves \& al., 2001; Yoder \& al., 2001). In a phylogenetic study of the tribe Crotalarieae, Boatwright \& al. (2008a) also found that in the absence of strongly supported incongruent patterns between datasets, the ILD test indicated significant incongruence and was unreliable to detect incongruent patterns compared to visual inspection. Their suggestion and that of Seelanan (1997) is therefore followed and datasets combined if no strongly supported incongruent patterns (85\%-100\% BS or "hard" incongruence) were detected.

No incongruent patterns were noticed between any of the datasets. Two combined analyses were conducted: (1) the ITS and rbcLa combined analysis (dataset 1; 186 accessions, 168 species); and (2) the ITS, matK, psbA-trnH and rbcLa com- bined analysis (dataset 2; 141 accessions, 131 species). These analyses included representatives of all major groups as classified by Polhill (1982) and most of the subsections (dataset 1) without missing data.

For BI (Huelsenbeck \& Ronquist, 2001; Ronquist \& Huelsenbeck, 2003) a partitioned analysis was implemented and the GTR $+\mathrm{I}+\mathrm{G}$ model selected for both the ITS and rbcLa datasets, the TVM $+\mathrm{G}$ model for the matK dataset, and the GRT $+\mathrm{G}$ model for the $p s b A-\operatorname{trn} H$ dataset

\section{http://repository.uwc.ac.za}


indicated by ModelTest v.3.1.2 (Posada \& Crandall, 1998) using the Akaike information criterion (AIC). The BI analyses were run in MrBayes v.3.1.2 for a total of 16 million generations sampling every 10,000 generations for dataset 1 and 11 million generations sampling every 10,000 generations for dataset 2. Tracer v.1.5.0 (Rambaut \& Drummond, 2009) was used to assess convergence, compar- ing traces of two simultaneous analyses, determining whether adequate sample sizes (ESS) were used for each parameter, if the MCMC parameter samples were taken from a stationary, unimodal distribution, and whether stationarity of posterior probabilities of splits within runs were reached. After the anal- yses were completed, $25 \%$ of the trees were removed as the "burn-in" and majority-rule consensus trees were produced for each of the two analyses. Posterior probability (PP) values (only those above 0.5 are indicated) were evaluated according to the following scale: $0.50-0.94$, weak; 0.95-1.00, strong.

\section{Results}

Statistics for each dataset obtained in the parsimony analy- ses are listed in Table 2.

Combined ITS and rbcLa dataset. - The bootstrap con- sensus trees from the individual ITS and $r b c L a$ datasets were compared and no evidence of strongly supported incongruent patterns was found. These two datasets were combined into a single analysis, because it contained the largest number of spe- cies for which both regions were successfully sequenced and resulted in a well-resolved phylogeny at the terminal clades. Crotalaria is monophyletic (99\% BS, PP 1.0) with well-resolved clades corresponding to some of Polhill's (1982) infrageneric groups (Fig. 2).

Combined ITS, matK, psbA-trnH and rbcLa dataset. - Both the MP and BI analyses showed similar results in the total combined analysis (Fig. 3) and indicated that Crotalaria is monophyletic (99\% BS, PP 1.0). The phylogeny is fairly well-

resolved at the branch ends, with a total of 15 clades that were identified, but with an unresolved backbone. Nine of these clades correspond to the infrageneric concepts as proposed by Polhill (1982) as either sections or subsections.

\section{Discussion}

The molecular phylogeny (Figs. 2, 3) reveals eleven mono- phyletic groups that are variously supported by bootstrap per- centages, Bayesian posterior probabilities and morphological evidence. Monophyletic groups are supported by combinations of morphological characters rather than single, unambiguous synapomorphies. These unique combinations are listed in Table 3 and are briefly discussed for each clade:

1. Hedriocarpae clade (PP 0.56). All species have ridge callosities present on the standard petal blade and claw, a rounded (rarely angled) keel with an untwisted beak and a rounded (rarely geniculate) style with trichomes in one line. Most species have a truncate calyx (sometimes only slightly so) with bracteoles inserted at the base or just below the calyx. The five calyx lobes are shorter than the keel and more or less subequally lobed or as long as the keel and slightly bilabiate. Petals often have purple or brown-coloured venation.

\section{http://repository.uwc.ac.za}


2. Stipulosae clade (77\% BS, PP 1.00). Asymmetrical stip- ules are present in most of the species. Ridge callosities are in- variably present on the standard petal blade and claw. The keel is somewhat rounded or subangled at about or below the middle to angled in the lower third with an untwisted beak (rarely incurved, becoming slightly coiled) and lanate hairs along the upper edge. The fruit is usually cylindrical or oblong-ellipsoid.

3. Geniculatae clade (72\% BS, PP 0.96). Columnar or disc callosities are restricted to the standard petal blade. The keel is angled in the lower third with an untwisted beak and a geniculate style with one (those with disc callosities) or two (those with columnar callosities) lines of hairs (amphistylar hairs present in C. monophylla). The fruit is thick-walled (if somewhat thin-walled, then inflorescences with twelve or more flowers).

Table 2. Statistics obtained for the parsimony analyses for each of the four individual regions sequenced (ITS, $m a t K, p s b A-t r n H, r b c L a$ ) as well as the combined ITS and $r b c L a$ regions (dataset 1) and combined ITS, $m a t K, p s b A$-trnH and $r b c L a$ regions (dataset 2).

\begin{tabular}{lllllll}
\hline & ITS & matK & $p s b A-t r n H$ & $r b c L a$ & $\begin{array}{l}\text { Dataset 1 } \\
\text { (ITS, } r b c L a)\end{array}$ & $\begin{array}{l}\text { Dataset 2 (ITS, } m a t K, \\
p s b \text { - trmH, } r b c L a)\end{array}$ \\
\hline No. of included accessions & 235 & 161 & 211 & 198 & 186 & 141 \\
No. of included taxa & $207(30 \%)$ & $145(21 \%)$ & $190(27 \%)$ & $178(25 \%)$ & $168(24 \%)$ & $131(19 \%)$ \\
No. of included characters & 818 & 720 & 610 & 552 & 1355 & 2671 \\
No. of variable characters & $588(72 \%)$ & $214(30 \%)$ & $291(48 \%)$ & $95(17 \%)$ & $462(34 \%)$ & $832(31 \%)$ \\
No. of parsimony-informative sites & $404(49 \%)$ & $103(14 \%)$ & $166(27 \%)$ & $64(12 \%)$ & $304(22 \%)$ & $474(18 \%)$ \\
No. of trees (Fitch) & 1920 & 9661 & 80 & 2440 & 5180 & 6450 \\
No. of steps (tree length) & 2419 & 386 & 1960 & 455 & 1552 & 2059 \\
Consistency index (CI) & 0.39 & 0.67 & 0.22 & 0.25 & 0.43 & 0.54 \\
Retention index (RI) & 0.70 & 0.87 & 0.21 & 0.31 & 0.80 & 0.80 \\
\hline
\end{tabular}



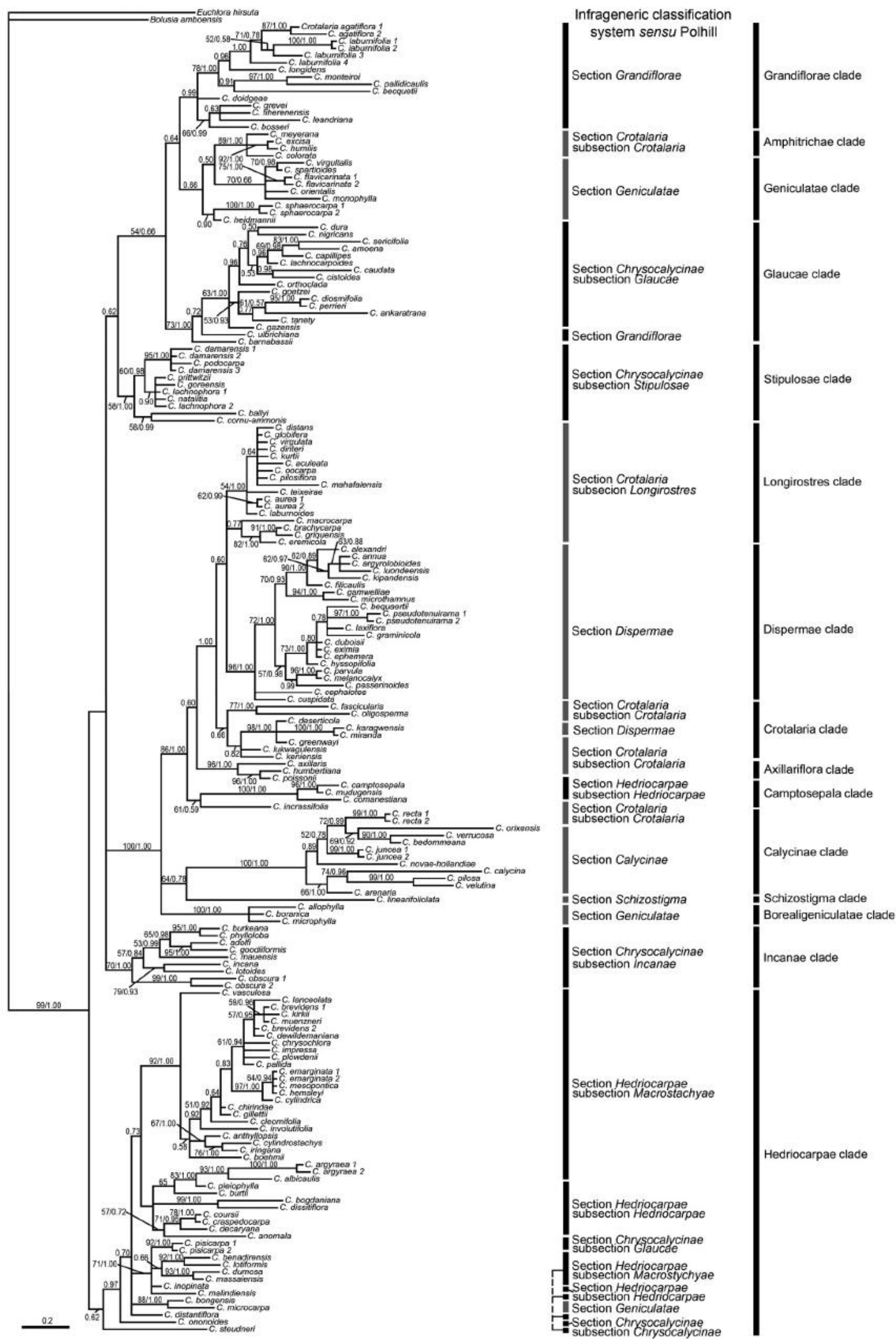

Fig. 2. The combined ITS and $r b c L a$ analysis (dataset 1) of 168 species (186 accessions) produced similar trees in the Bayesian and maximum parsimony (tree length $=1552$, consistency index $=0.43$, retention index $=0.80$ ) analyses. A $50 \%$ majority-rule phylogram from the $\mathrm{BI}$ is illustrated with bootstrap percentages above $50 \%$ indicated left of the forward slash and posterior probability values above 0.5 right of the forward slash. A total of 15 clades were identified and compared with the current classification system proposed by Polhill (1982). Sections forming part of Polhill's "specialised" group are shown in grey and sections included in the "unspecialised" group are shown in black. The number of expected substitutions per site is indicated by the scale.

$$
\text { http://repository.uwc.ac.za }
$$




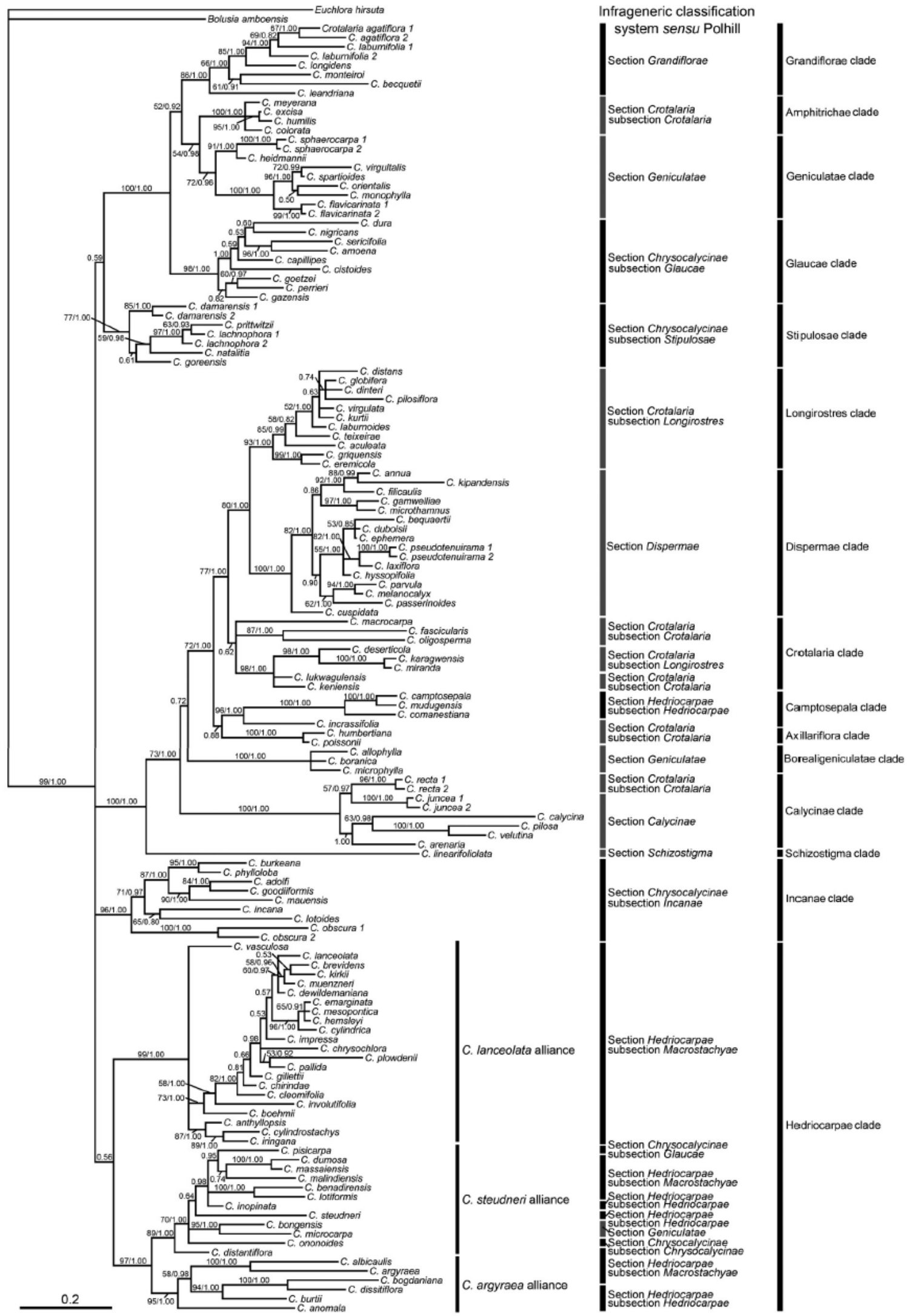

Fig. 3. The combined ITS, matK, psbA-trnH and $r b c L a$ analysis (dataset 2) of 131 species (141 accessions) produced similar trees in the Bayesian and maximum parsimony (tree length $=2059$, consistency index $=0.54$, retention index $=0.80$ ) analyses. A $50 \%$ majority-rule phylogram from the BI is illustrated with bootstrap percentages above $50 \%$ indicated left of the forward slash and posterior probability values above 0.5 right of the forward slash. A total of 15 clades were identified and compared with the current classification system proposed by Polhill (1982). Sections considered by Polhill to be "specialised" are indicated in grey and those considered as "unspecialised" are indicated in black. The number of expected substitutions per site is indicated by the scale. 
Table 3. A comparison of morphological diagnostic characters (brackets indicate rare character states) for each of the eleven recognized infrageneric groups of the genus Crotalaria.

\begin{tabular}{|c|c|c|c|c|c|c|c|c|c|c|c|}
\hline Character & 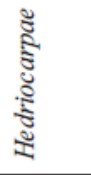 & : & 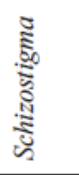 & కัँ & 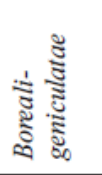 & $\frac{\sqrt[3]{3}}{\sqrt[3]{3}}$ & 宽 & క్ & 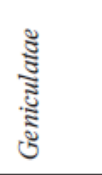 & 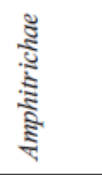 & 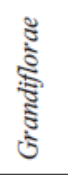 \\
\hline $\begin{array}{l}\text { Habit } \\
(- \text { tree, }+ \text { shrub, ++ perennial, }+++ \text { annual })\end{array}$ & $\begin{array}{l}+1 \\
++1 \\
++1\end{array}$ & $\begin{array}{l}+/++ \\
++ \\
+\ldots\end{array}$ & $\begin{array}{l}(++1 \\
(++2\end{array}$ & $\begin{array}{l}(+) /++1 \\
+++\end{array}$ & $\begin{array}{l}+4 \\
++\end{array}$ & $\begin{array}{l}(+) /++1 \\
+++ \\
+\cdots+\cdots\end{array}$ & $\begin{array}{l}(++) /++1 \\
(++)\end{array}$ & $\begin{array}{l}(+++) \\
+1+1\end{array}$ & $\begin{array}{l}(+) /++1 \\
+++\end{array}$ & $H /+H+$ & $-1+$ \\
\hline $\begin{array}{l}\text { Leaves } \\
(- \text { simple },+ \text { compound })\end{array}$ & + & + & + & $-/(+)$ & + & $(-) /+$ & + & $-/+$ & $(-) /+$ & + & $(-) /+$ \\
\hline $\begin{array}{l}\text { Stipule symmetry } \\
\text { (- absent or inapplicable, }+ \text { symmetrical, } \\
++ \text { assymmetrical) }\end{array}$ & + & + & + & $+/++$ & $-1+$ & $-1+$ & $(-) /++$ & $\begin{array}{l}-/+1 \\
(++)\end{array}$ & $-/+$ & + & $-/+$ \\
\hline $\begin{array}{l}\text { Stipule shape } \\
(- \text { not decurrent },+ \text { decurrent })\end{array}$ & - & - & - & $-1+$ & - & - & - & - & - & - & - \\
\hline $\begin{array}{l}\text { Bracteole position } \\
\text { (- absent or inapplicable },+ \text { on or below } \\
\text { calyx, ++ on pedicel) }\end{array}$ & + & + & $-/++$ & $+/(++)$ & + & $+/++$ & + & $(+) /++$ & ++ & + & ++ \\
\hline $\begin{array}{l}\text { Calyx type } \\
(-5 \text {-subequally lobed, + 4-subequally } \\
\text { lobed, ++ bilabiate })\end{array}$ & $-/(++)$ & - & - & $(-) /++$ & - & - & - & $-/+$ & - & - & - \\
\hline $\begin{array}{l}\text { Calyx tube } \\
(- \text { campanulate, }+ \text { truncate })\end{array}$ & $(-) /+$ & - & - & - & - & - & - & - & - & - & - \\
\hline $\begin{array}{l}\text { Calyx length } \\
(- \text { shorter than keel, + as long as keel, } \\
++ \text { longer than keel) }\end{array}$ & $-/(+)^{a}$ & + & + & $\begin{array}{l}(-) /+1 \\
++\end{array}$ & - & $-/(+)$ & $(-) /+$ & $(-) /+$ & - & $-/(+)$ & - \\
\hline $\begin{array}{l}\text { Callosity shape } \\
\text { (+ ridge, ++ disc, }+++ \text { lamelliform, } \\
++++ \text { columnar) }\end{array}$ & + & + & ++ & ++ & $\begin{array}{l}++1 \\
(++++)\end{array}$ & ++ & + & + & $\begin{array}{l}(++) / \\
+H+1\end{array}$ & + & + \\
\hline $\begin{array}{l}\text { Flower size } \\
(- \text { less than } 16 \mathrm{~mm},+ \text { more than } 16 \mathrm{~mm})\end{array}$ & - & $-1+$ & - & $-1+$ & - & $-/+$ & $-1+$ & - & $-/+$ & - & $(-) /+$ \\
\hline $\begin{array}{l}\text { Keel shape } \\
(- \text { rounded, + subangled, ++ angled })\end{array}$ & $\begin{array}{l}-1+1 \\
(++)\end{array}$ & $-/+/++$ & - & $\begin{array}{l}(-) /+1 \\
+\end{array}$ & $-/+$ & $+/++$ & $+/++$ & $-/+$ & ++ & - & - \\
\hline $\begin{array}{l}\text { Keel curvature } \\
(- \text { about the middle, }+ \text { below the middle, } \\
++ \text { lower third) }\end{array}$ & $\begin{array}{l}-/+/ \\
(++)\end{array}$ & $\begin{array}{l}(-) /+1 \\
++\end{array}$ & $(-) /+$ & $\begin{array}{l}(-) /+1 \\
++\end{array}$ & $-1+$ & $+/++$ & $\begin{array}{l}(-) /+1 \\
++\end{array}$ & $-1+$ & ++ & - & $-1+$ \\
\hline $\begin{array}{l}\text { Keel vestiture (upper edge) } \\
\text { (- glabrous or ciliate, + lanate-pubescent) }\end{array}$ & - & $(-) /+$ & - & - & - & $-/(+)$ & + & - & - & - & - \\
\hline $\begin{array}{l}\text { Keel beak } \\
\left(- \text { flat, }+ \text { circumflexed up to } 90^{\circ},\right. \\
\left.++ \text { twisted more than } 90^{\circ}\right)\end{array}$ & - & - & ++ & + & - & $(-)^{b /+1+}$ & - & $-1+$ & - & + & - \\
\hline $\begin{array}{l}\text { Style curvature } \\
\text { (- rounded, + geniculate) }\end{array}$ & $-/(+)$ & $-/(+)$ & - & $(-) /+$ & + & $-1+$ & $-/(+)$ & - & + & - & - \\
\hline $\begin{array}{l}\text { Stylar trichome distribution } \\
\text { (+ one line, }++ \text { two lines, }+++ \text { all around) }\end{array}$ & + & $+/(++)$ & ++ & $+1++$ & $+/++$ & ++ & + & $+/++$ & $\begin{array}{l}(+) /++1 \\
(+++)\end{array}$ & +++ & + \\
\hline $\begin{array}{l}\text { Stigma } \\
(- \text { contracted }+ \text { dilated and bifurcate })\end{array}$ & - & - & + & - & - & - & $-/(+)$ & - & - & - & - \\
\hline $\begin{array}{l}\text { Fruit wall } \\
(- \text { thick, }+ \text { thin })\end{array}$ & - & + & $(-) /+$ & $-/(+)$ & + & - & - & $-1+$ & $-/(+)^{c}$ & - & - \\
\hline $\begin{array}{l}\text { Fruit stipe }^{\mathrm{d}} \\
(- \text { absent/short, + long })\end{array}$ & - & $-/(+)$ & - & - & - & $-/(+)$ & - & - & - & - & $(-) /+$ \\
\hline
\end{tabular}

${ }^{a}$ If as long, then calyx slightly bilabiate, but style rounded with a single line of hairs.

${ }^{b}$ If keel not twisted, then keel beak blunt and wing petals as long as or longer than the keel.

${ }^{\mathrm{C}}$ If slightly thin-walled, then inflorescences 12 to many-flowered.

d Short-stipitate implies that the stipe is usually up to $7 \mathrm{~mm}$ long; long-stipitate implies that the stipe is usally more than $7 \mathrm{~mm}$ long. 
1. Amphitrichae clade (100\% BS, PP 1.0). Ridge callosities are invariably present on the standard petal blade and claw. The keel is rounded with a twisted beak (usually twisted more than $270^{\circ}$ ). The style is invariably rounded with hairs distributed all around.

2. Grandiflorae clade (86\% BS, PP 1.0). All species are either shrubs or trees. Flowers are often very large (up to $55 \mathrm{~mm}$ long) with prominent hypanthia. Ridge callosities are invaria- bly present on the standard petal blade and claw, and the keel is rounded at about or below the middle with a rounded style and trichomes in one line. The fruit is invariably stipitate (often very long-stipitate; stipe up to $95 \mathrm{~mm}$ long in C. laburnifolia).

3. Glaucae clade (98\% BS, PP 1.0). This group includes robust perennial herbs that become somewhat woody or rarely annuals. Ridge callosities are present on the standard petal blade and claw. The keel is rounded at about the middle, often with the upper edge crested and the beak circumflexed up to $90^{\circ}$ or subangled below the middle with an untwisted beak. The calyx is usually more than two thirds as long as the keel or as long as the keel. The style is invariably rounded with one or two lines of hairs.

4. Incanae clade (96\% BS, PP 1.0). Ridge callosities are present on the standard petal blade and claw. The calyx is deeply lobed and more or less as long as the keel with curved bracteoles ascending from the top of the pedicel (often at the base of the calyx). The keel is rounded at about the middle or angled in the lower third and the style is rounded or geniculate with one (rarely two) line of hairs. Fruits are oblong-clavate to fusiform, thin-walled (rarely thick-walled) and shortly stipitate or sessile.

5. Schizostigma clade. Three diminutive species with very small flowers and disc callosities restricted to the standard petal blade. The keel is deeply rounded at about or below the middle with a twisted beak (circumflexed $180^{\circ}$ ) and the style dilated or sometimes bifurcate at the tip with hairs in two lines.

6. Calycinae clade (100\% BS, PP 1.0). Lamelliform callosi- ties are invariably present on the standard petal blade. The calyx is usually bilabiate (rarely subequally lobed) and often as long as the keel. A subangled keel (rounded if the calyx is subequally lobed or sometimes angled in the lower third) is usually present with a twisted beak. The style is rounded or geniculate with hairs in one or two lines. The leaves are usually simple and less often compound. Bracteoles are often inserted at the base of the calyx.

7. Borealigeniculatae clade (100\% BS, PP 1.0). Disc or columnar callosities are restricted to the standard petal blade. The keel is rounded or subangled below the middle with an untwisted beak and the style is invariably geniculate with one or two lines of hairs. The fruit is invariably thin-walled.

8. Crotalaria s.l. clade (Axillariflora, Crotalaria, Camp- tosepala, Dispermae and Longirostres clades, $72 \%$ BS, PP 1.0). All species have disc callosities restricted to the standard petal blade. The 
keel is either rounded below the middle (rarely at about the middle) or angled in the lower third. A twisted keel beak is usually present but is absent in those species with deeply rounded keels with blunt beaks and wings that are more or less as long as or longer than the keel. The style is rounded (in those species with rounded or subangled keels) and geniculate (species with angled keels) and hairs are distributed in two lines.

The molecular phylogeny is not in exact agreement with Polhill's (1982) classification system. The following uncer- tainties have been resolved in this study: (1) The genus can- not be divided into two subgenera because of convergences in the position and shape of the standard petal callosities (see Le Roux, 2011). (2) The three species alliances of the Hedri- ocarpae clade (Fig. 3) are incongruent with the circumscrip- tions of the two subsections of section Hedriocarpae and no apomorphies are currently available to support a division of section Hedriocarpae. (3) Section Chrysocalycinae is paraphy- letic, but three of the subsections form monophyletic groups, namely the Stipulosae, Incanae and Glaucae clades. Subsection Chrysocalycinae is embedded within the Hedriocarpae clade and subsection Tetralobocalyx is embedded within the Glaucae clade. The diversity within section Chrysocalycinae can only be accommodated by recircumscribing the main monophyletic groups as sections (i.e., by raising subsections to sectional sta- tus). (4) Section Geniculatae is paraphyletic (Geniculatae and Borealigeniculatae clades). Species with a southern African distribution (including widely distributed species) form part of the Geniculatae clade and the species restricted to the northern parts of northeast tropical Africa, northern Africa and the Arabian Peninsula are included in the Borealigeniculatae clade. (5) The Amphitrichae clade forms a strongly supported monophyletic group (100\% BS, PP 1.00 and five synapomorphies) that does not belong in section Crotalaria. This clade has been described as a new section (Le Roux \& Van Wyk, 2013). (6) The sectional status of section Calycinae is justified (Bisby \& Polhill, 1973) and it should not be included in section Crota- laria. Concerns previously raised by Polhill (1982) with regard to the placement of $C$. recta, C. spectabilis and allies are here clarified-they belong to the Calycinae clade (represented by $C$. recta in the phylogeny). This placement is supported by the presence of lamelliform callosities on the standard petal blade. (7) Section Crotalaria subsection Crotalaria is paraphyletic (Axillariflora, Camptosepala and Crotalaria clades). With fur- ther study of the Axillariflora and Camptosepala clades, new apomorphies may be identified to support these clades as sub- sections. Furthermore, the Camptosepala clade is noteworthy because it includes species formerly placed in section Hedri- ocarpae but with disc callosities, stylar hairs in two lines and the absence of a twisted keel beak. Thulin (1991) was correct in suggesting that these species are misplaced in Hedriocarpae and that they are related to C. emarginella Vatke and allies of section Crotalaria subsection Crotalaria. This relationship is here confirmed by the molecular results. (8) The circumscrip- tion of Polhill's (1982) section Dispermae (Dispermae clade) received support but the section is now embedded within the Crotalaria s.l. clade. (9) The placement of individual species such as C. bongensis, C. microcarpa, C. boranica, C. microphylla, C. micans, C. pisicarpa and various others has also been clarified (see Le Roux, 2011).

Ansari (2008) modified Polhill's (1982) classification sys- tem to make provision for the Indian Crotalaria species. He used concepts from Wight \& Walker-Arnott (1834), Bentham (1843) and

\section{http://repository.uwc.ac.za}


Baker (1876) and recognized six sections and twelve subsections (Ansari, 2006, 2008). The system focused on the Indian species and did not take into account the full morphological diversity found in Africa. Discrepancies between Polhill's (1982) and Ansari's (2006, 2008) classification systems are mainly encountered in their sections Calycinae and Crotalaria (Table 1). Ansari $(2006,2008)$ created four subsections within each of these sections. Molecular data supports the concept of section Crotalaria subsection Longirostrae sensu Ansari but not the other three subsections (Bracteatae, Crotalaria, Poly- phyllae), all of which should be included in section Calycinae (Table 1).

The current study provides new insights into the phylog- eny of the genus Crotalaria and shows that several modifi- cations to Polhill's (1982) infrageneric classification system have become necessary, not only to accommodate non-African species but also to reflect the eleven main groups or clades shown in Figure 3. These groups are quite distinct and it is unlikely that their circumscriptions will have to be modified after more detailed studies. By recognizing these as sections, new sampling strategies will become possible for the first time.

In contrast, it is not yet possible to formalise groups (e.g., subsections) within the eleven sections recognized here. Fur- ther sampling is required (to include more species, especially of sections Hedriocarpae, Calycinae and section Crotalaria subsection Crotalaria) to determine relationships within the Hedriocarpae, Calycinae, Axillariflora, Camptosepala and Crotalaria clades (possibly creating subsections).

This study revealed that specialised features used by Polhill (1968) to define his sections and subsections are not only convergent but also not always logically correlated. For example, in $C$. bongensis and C. microcarpa of the Hedriocar- pae clade, a non-twisted keel co-occurs with a geniculate style, whereas in the Amphitrichae clade, a twisted keel co-occurs with a rounded style. It is clear that the evolution of specialised floral characters (shape and position of callosities, shape and position of the keel curvature, presence or absence of a twist in the keel, and shape and vestiture of the style) has been con- vergent and that the weighting of these characters has resulted in a partially artificial arrangement of species.

\section{Taxonomic treatment}

A first global infrageneric classification system is pre- sented and formalised below, based on molecular and morpho- logical evidence (Le Roux, 2011; Le Roux \& al., 2011; Le Roux \& Van Wyk, 2012). Eleven sections are recognized (derived from the clades in Fig. 3; broadened circumscriptions indicated by "s.l."): (1) section Hedriocarpae s.l. (Hedriocarpae clade); (2) section Incanae (Incanae clade, previously a subsection of section Chrysocalycinae); (3) section Schizostigma (Schiz- ostigma clade); (4) section Calycinae s.l. (Calycinae clade); (5) section Borealigeniculatae (Borealigeniculatae clade, a new section); (6) section Crotalaria s.l. (including the Axillariflora, Crotalaria, Dispermae, Camptosepala and Longirostres clades); (7) section Stipulosae (Stipulosae clade, previously a subsection of section Chrysocalycinae); (8) section Glaucae s.l. (Glaucae clade, previously a subsection of section Chrysocalycinae); (9) section Geniculatae (Geniculatae clade); (10) section Amphitrichae (Amphitrichae clade, a new

\section{http://repository.uwc.ac.za}


section); and (11) section Grandiflorae (Grandiflorae clade). Section Dispermae is in- cluded in section Crotalaria and subsections Tetralobocalyx and Chrysocalycinae (both formerly subsections of section Chrysocalycinae) are included in sections Glaucae and Hedri- ocarpae, respectively. The details of the broadened circum- scriptions of sections Hedriocarpae, Calycinae, Crotalaria and Glaucae are not indicated here but can be seen in the synonymy given below.

\section{Key to the sections of Crotalaria}

1. Standard petal callosities of the ridge type (Fig. 1A1); pre- sent on blade and claw 2

1. Standard petal callosities of the columnar (Fig. 1A2), disc (Fig. 1A3) or lamelliform (Fig. 1A4) types; present on blade only 7

2. Keel rounded at about the middle (Fig. 1B1, B3, B4); keel beak twisted (Fig. 1B2, B6); stylar trichomes all around distal part of style (Fig. 1 F3, F6) C. sect. Amphitrichae

2. Keel rounded at about or below the middle; keel beak not twisted (circumflexed up to $90^{\circ}$; Fig. 1B3); stylar trichomes in one or two lines (Fig. 1F1, F2, F4, F5) 3

3. Flowers usually more than $16 \mathrm{~mm}$ long (if shorter than $16 \mathrm{~mm}$, then stipules absent); large shrubs or trees; recepta- cle prominent, 2-9 mm long; calyx campanulate (Fig. 1C2), never truncate; fruit oblong-clavate, often long-stipitate

\section{C. sect. Grandiflorae}

3. Flowers less than $16 \mathrm{~mm}$ long (if longer than $16 \mathrm{~mm}$, then stipules present, but if stipules absent, then keel lanate along the upper edge or bracteoles inserted at the base of the calyx); mostly annuals or perennials, rarely shrubs; receptacle not prominent, less than $2 \mathrm{~mm}$ long (rarely up to $\pm 4 \mathrm{~mm}$ long); calyx sometimes truncate (Fig. 1C1); fruit shape variable, rarely longstipitate .................. 4

3 Keel with upper edge glabrous or ciliolate (Fig. 1B1-B3);

keel beak sometimes circumflexed up to $90^{\circ}$......... 5

4. Keel with upper edge lanate (Fig. 1B4) to slightly tomen- tose (if glabrous, then stipules conspicuously cordate-fal- cate and asymmetrical); keel beak never twisted ..... 6

4 Bracteoles usually inserted at the base of the calyx (Fig.

1E2); stylar trichomes invariably in one line along the upper edge of the style (Fig. 1F1, F4); calyx often truncate (Fig. $1 \mathrm{C} 1$ ) and up to half as long as the keel; petals com- monly distinctly veined brown (Fig. 1C1), purple or red; keel rounded without a crest or circumflexed beak (Fig. 1B1) or rarely angled (if angled, then style geniculate; Fig. 1F8) .........................

\section{Hedriocarpae}

5. Bracteoles variously inserted on the pedicel (rarely at the base of the calyx; Fig. 1E1); stylar trichomes in one line along the upper edge of the style (Fig. 1F1, F4) or in two lines along the upper and lower edges of the style (Fig. $1 \mathrm{~F} 2, \mathrm{~F} 5$ ); calyx never truncate and usually more than half as long as the keel; petals not distinctly veined purple or red (Fig. 1C2); keel rounded with a crest and sometimes circumflexed beak (Fig. 1B3) or sub-angled (Fig. 1B2) to angled in the lower half (but never with a geniculate style)

C. sect. Glaucae

\section{http://repository.uwc.ac.za}


6. Stipules linear; bracteoles almost always curved and as- cending from the pedicel or base of the calyx, filiform to ovate, persistent; calyx \pm as long as keel; fruit oblong- clavate or fusiform and thin-walled .... C. sect. Incanae

6 Stipules expanded and leaf-like (linear or absent if leaves unifoliolate); bracteoles not curved and ascending from the pedicel, filiform to linear-lanceolate, caducous; calyx shorter than the keel; fruit cylindrical or oblong-ellipsoid and thick-walled ................... C. sect.

\section{Stipulosae}

7 Keel beak not twisted (Fig. 1B5); style geniculate (Fig.

1F8); fruit subglobose or ellipsoid to oblong-obovoid; cal- losities of the columnar (Fig. 1A2) or rarely disc (Fig. 1A3) type 8

7. Keel beak usually twisted (Fig. 1B2 and B6; if not twisted, then calyx lobes \pm as long as the keel with wings as long or longer than the keel) (Fig. 1B6); style rounded or genicu- late (Fig. $1 \mathrm{~F} 7$ and F8 respectively); fruit shape various; callosities of the lamelliform (Fig. 1A4) or disc (Fig. 1A3) type ........................................... 9

8. Keel rounded below the middle or subangled in lower third; fruit subglobose-ellipsoid to oblong-obovoid and thin-walled; distributed in northeast Tropical Africa, northern Africa and extending into the Arabian Peninsula

\section{C. sect. Borealigeniculatae}

9. Keel angled in the lower third; fruit oblong-ellipsoid and thick-walled (if thin-walled, then located in southern Africa); widely distributed in Africa, concentrated in south- ern and South Tropical Africa ...... C. sect. Geniculatae

10. Callosities lamelliform (Fig. 1A4); keel rounded (Fig. 1B1) or subangled (Fig. 1B2) below the middle, rarely angled in the lower third (Fig. 1B5, B6) and invariably with a twisted beak (Fig. 1B2, B6); calyx more than half as long as the keel to longer than the keel and deeply lobed, often bilabiate (Fig. 1D2); leaves usually simple, rarely trifolio- late ............................. C. sect. Calycinae

9. Callosities disciform (Fig. 1A3); keel subangled below the middle (Fig. 1B2) or angled in the lower third (Fig. 1B5, B6) and usually with a twisted beak (Fig. 1B2, B6; if not twisted, then calyx lobes \pm as long as the keel with wings as long or longer than the keel); calyx usually shorter than the keel (if equal or longer, then keel not twisted or style dilated and bifurcate at the tip) and equally or sub-equally lobed (Fig. 1D1); leaves uni- to trifoliolate, rarely simple ......... 10

10. Calyx as long as the keel; keel beak twisted; style dilated and bifurcate at the tip ............. C. sect. Schizostigma

10. Calyx shorter than the keel (calyx as long as or longer than keel if beak not twisted); keel beak twisted; style not dilated and bifurcate at the tip C. sect. Crotalaria

1. Crotalaria sect. Hedriocarpae Wight \& Arn., Prodr. Fl.

Ind. Orient. 1: 194. 1834, emend. nov. M.M. le Roux \& B.-E. van Wyk - Type: C. clavata Wight \& Arn.

$=$ Chrysocalyx Guill. \& Perr. in Guillemin \& al., Fl. Seneg. Tent.: 157, t. 43. $1831 \& 1832 \equiv$ Crotalaria subg. Chryso- calyx (Guill. \& Perr.) Meisn., Pl. Vasc. Gen.: Tab. Diagn. 82, Commentarius 58. 1837 - Type (designated by Cowan, 1959): Chrysocalyx ebenoides Guill. \& Perr.

\section{http://repository.uwc.ac.za}


$=$ Priotropis Wight \& Arn., Prodr. Fl. Ind. Orient. 1: 180. $1834 \equiv$ Crotalaria subg. Priotropis (Wight \& Arn.) Meisn., Pl. Vasc. Gen.: Tab. Diagn. 82, Commentarius 58. 1837 E. subsect. Priotropis (Benth. ex Wight \& Arn.) Polhill in Kew Bull. 22: 247. 1968 - Type: P. cytisoides (Roxb.) Wight \& Arn. (三C. cytisoides Roxb.).

= Crotalaria [unranked] Chrysocalycinae Benth. in London J. Bot. 2: 571. 1843; Baker in Oliver, Fl. Trop. Afr. 2: 8. 1871, pro parte $\equiv C$. ser. Chrysocalycinae (Benth.) Taub. in Engler \& Prantl, Nat. Pflanzenfam. 3(3): 229. $1893 \equiv$ C. sect. Chrysocalycinae (Benth.) Baker f. in J. Linn. Soc., Bot. 42: 305. $1914 \equiv$ C. subsect. Chrysocalycinae (Benth.) Bisby \& Polhill in New Phytol. 72: 732, 741. 1973 - Type (designated by Polhill, 1968): C. ebenoides (Guill. \& Perr.) Walp.

= Crotalaria [unranked] Farctae Benth. in London J. Bot. 2: $583.1843 \equiv$ C. sect. Farctae (Benth.) Bakerf. in J. Linn. Soc., Bot. 42: 308. 1914 - Type: C. lupinoides Hochst. ex Benth.

= Crotalaria [unranked] Cytisoides Benth. in London J. Bot. 2: $591.1843-$ Type: C. cytisoides Hils. \& Bojer ex Benth. 1843, nom. illeg., non Roxb. 1825 nec Wight 1831 (= C. ibi- tyensis R. Vig. \& Humbert).

= Maria-antonia Parl. in Maria Antonia: 3. 1844 - Type: M. orientalis Parl. $(=C$. microcarpa Hochst. ex Benth.).

= Crotalaria sect. Coursia Peltier in J. Agric. Trop. Bot. Appl. 6: 267. 1959 - Type: C. coursii Peltier.

= Crotalaria [unranked] Macrostachyae Benth. in London J. Bot. 2: $583.1843 \equiv$ C. ser. Macrostachyae (Benth.) Taub. in Engler \& Prantl, Nat. Pflanzenfam. 3(3): 227. $1893 \equiv$ C. sect. Macrostachyae (Benth.) Polhill in Kew Bull. 22: 261. $1968 \equiv$ C. subsect. Macrostachyae (Benth.) Bisby \& Polhill in New Phytol. 72: 741.1973 - Type (designated by Polhill, 1968): C. pallida Aiton (= C. striata DC.).

The two subsections of $C$. sect. Hedriocarpae are amalgamated and the circumscription is broadened to include $C$. sub- sect. Chrysocalycinae.

2. Crotalaria sect. Incanae (Benth.) Polhill in Kew Bull. 22: 217. $1968 \equiv$ C. [unranked] Incanae Benth. in London J. Bot. 2: 587. $1843 \equiv$ C. ser. Incanae (Benth.) Taub. in Engler \& Prantl, Nat. Pflanzenfam. 3(3): 229. $1893 \equiv$ C. subsect. Incanae (Benth.) Bisby \& Polhill in New Phytol. 72: 741.1973 - Type: C. incana L.

= Phyllocalyx A. Rich., Tent. Fl. Abyss. 1: 160. 1847 - Type: P. quartinianus A. Rich. (三C. quartiana A. Rich.).

The delimitation of the section follows the original sec- tional concept of Polhill (1968).

3. Crotalaria sect. Schizostigma Polhill in Kew Bull. 22: 297. 1968 - Type: C. leptocarpa Balf. f.

The circumscription of this small section (Polhill, 1968) remains the same but excludes C. ballyi, the only species with asymmetrical (falcate-cordate) stipules, which now forms part of $C$. sect. Stipulosae. 
4. Crotalaria sect. Calycinae Wight \& Arn. in Prodr. Fl. Ind. Orient. 1: 181. 1834, emend. nov. M.M. le Roux \& B.-E. van Wyk - Type: C. calycina Schrank.

$=$ Crotalaria sect. Alatae Wight \& Arn. in Prodr. Fl. Ind. Ori- ent. 1: $181.1834 \equiv$ C. ser. Alatae (Wight \& Arn.) Taub. in Engler \& Prantl, Nat. Pflanzenfam. 3(3): 228. $1893 \equiv$ C. subsect. Alatae (Wight \& Arn.) A.A. Ansari in J. Econ. Taxon. Bot. 30: 572. 2006 - Type (designated by Polhill, 1968): C. scabrella Wight \& Arn.

= Crotalaria [unranked] Arenariae Benth. in London J. Bot. 2: 473. $1843 \equiv C$. sect. Arenariae (Benth.) Baker in Hooker, Fl. Brit. India 2: 65. $1876 \equiv C$. ser. Arenariae (Benth.) Taub. in Engler \& Prantl, Nat. Pflanzenfam. 3(3): 228. 1893 - Type: C. arenaria Benth.

$=$ Crotalaria sect. Bracteatae Wight \& Arn. in Prodr. Fl. Ind. Orient. 1: 183. $1834 \equiv C$. subsect. Bracteatae (Wight \& Arn.) A.A. Ansari in J. Econ. Taxon. Bot. 30: 576. 2006 Type (designated by Ansari, 2006): C. paniculata Willd.

= Crotalaria sect. Diffusae Wight \& Arn. in Prodr. Fl. Ind. Orient. 1: 188. $1834 \equiv$ C. ser. Diffusae (Wight \& Arn.) Taub. in Engler \& Prantl, Nat. Pflanzenfam. 3(3): 228. $1893 \equiv C$. subsect. Diffusae (Wight \& Arn.) A.A. Ansari in J. Econ. Taxon. Bot. 30: 573. 2006 - Type (designated by Polhill, 1968): C. bifaria L.

$=$ Crotalaria sect. Erectae Wight \& Arn. in Prodr. Fl. Ind. Orient. 1: $186.1834 \equiv C$. subsect. Retusae Wight \& Arn. in Prodr. Fl. Ind. Orient. 1: 186. 1834 - Type: C. retusa L.

= Crotalaria sect. Eriocarpae Wight \& Arn. in Prodr. Fl. Ind. Orient. 1: 185. $1834 \equiv C$. ser. Eriocarpae (Wight \& Arn.) Taub. in Engler \& Prantl, Nat. Pflanzenfam. 3(3): 228. 1893 Type (designated by Polhill, 1968): C. juncea L.

= Crotalaria sect. Fulvae Wight \& Arn. in Prodr. Fl. Ind. Ori- ent. 1: 182. 1834 - Type: C. fulva Roxb.

= Crotalaria sect. Microcarpae Wight \& Arn. in Prodr. Fl. Ind. Orient. 1: $191.1834-$ Type (designated by Ansari, 2006): C. nana Burm.f.

= Crotalaria sect. Podocarpae Wight \& Arn. in Prodr. Fl. Ind. Orient. 1: 193. 1834 - Type (designated by Polhill, 1968): C. orixensis Rottler ex Willd.

= Crotalaria sect. Polyphyllae Wight \& Arn. in Prodr. Fl. Ind. Orient. 1: 194. $1834 \equiv C$. subsect. Polyphyllae (Wight \& Arn.) A.A. Ansari in J. Econ. Taxon. Bot. 30: 578. 2006 Type (designated by Polhill, 1968): C. quinquefolia L.

= Crotalaria sect. Sphaerocarpae Wight \& Arn. in Prodr. Fl. Ind. Orient. 1: 190. 1834 - Type (designated by Polhill, 1968): C. biflora L.

= Crotalaria subg. Iocaulon Raf., New Fl. 2: 53.1837 - Type (designated here): C. sagittalis L.

= Crotalaria [unranked] Multifoliolatae Baker in Hooker, Fl. Brit. India 2: 84.1876 - Type (designated here): C. quin- quefolia $\mathrm{L}$.

$=$ Crotalaria subsect. Heylandiae A.A. Ansari in J. Econ. Taxon. Bot. 30: 574. 2006 - Type: C. hebecarpa (DC.) Rudd.

The circumscription of this section is here broadened to include $C$. spectabilis and allies of $C$. subsect. Crotalaria (Polhill, 1982), as well as $C$. subsect. Bracteatae, C. subsect. 
Crotalaria (sensu A.A. Ansari) and C. subsect. Polyphyllae (Ansari, 2006, 2008). Crotalaria subsect. Crotalaria as cir- cumscribed by Ansari (2006, 2008) fits with $C$. sect. Calycinae but does not include the type of the genus (C. lotifolia L.). It is consequently excluded from the synonymy. Callosities are invariably lamelliform and therefore a useful diagnostic character.

5. Crotalaria sect. Borealigeniculatae M.M. le Roux \& B.-E. van Wyk, sect. nov. - Type: $C$. allophylla Thulin. Sectio Borealigeniculatae sectioni Geniculatis similis est, sed carina rotundata ad subangularem curvatura circum vel infra media, lobis calycis 2-3 plo longioribus tubo et fructibus parietibus gracilibus differt (in sectione Geniculatis carina angulata curvatura in triente inferior, lobis calycis brevioribus ad longiores tubo et fructibus crassiparietibus).

A small group (C. allophylla, C. boranica, C. microphylla) that is morphologically similar to $C$. sect. Geniculate in having untwisted keel beaks and geniculate styles. However, $C$. sect. Borealigeniculatae is restricted to northern areas of Africa (Egypt, Eritrea, Ethiopia, northeast Kenya, Somalia, Sudan; C. microphylla has a wider distribution in west and north- east tropical Africa) and the Arabian Peninsula (Saudi Arabia, Yemen). These species have rounded to subangled keel petals with the curvature at about or below the middle, columnar disc callosities, calyx lobes that are two to three times longer than the tube and subglobose-ellipsoid fruits with thin walls. Species from $C$. sect. Geniculatae are mostly found in south- ern Africa and Angola, with a few widespread. They all have angled keel petals with the curvature in the lower third, disc or columnar callosities; calyx lobes that are shorter to longer than the tube (if more than twice as long as the tube, fruit not thin-walled and species found in southern Africa) and ob- long-obovoid to cylindrical fruit (less commonly subglobose) with thick valves.

6. Crotalaria L. sect. Crotalaria, emend. M.M. le Roux \& B.-E. van Wyk - Type: $C$. lotifolia $\mathrm{L}$.

= Crotalaria sect. Dispermae Wight \& Arn. in Prodr. Fl. Ind. Orient. 1: 191. 1834, syn. nov. $\equiv C$. [unranked] Med-icagineae Benth. in London J. Bot. 2: 577. 1843 - Type: C. medicaginea Lam. (typified for $C$. sect. Dispermae by Polhill, 1968).

= Crotalaria [unranked] Vulgares Benth. in London J. Bot. 2: 592. 1843 - Type: C. macrocarpa E. Mey.

$=$ Crotalaria [unranked] Longirostres Benth. in London J. Bot. 2: $580.1843 \equiv C$. ser. Longirostres (Benth.) Taub. in Engler \& Prantl, Nat. Pflanzenfam. 3(3): 229. $1893 \equiv$ C. subsect. Longirostres (Benth.) Polhill in Kew Bull. 22: 312. 1968 - Type (designated by Polhill, 1968): C. distans Benth.

= Crotalaria [unranked] Oocarpae Baker in Oliver, Fl. Trop. Afr. 2: 9. $1871-$ Type (designated by Polhill, 1938): C. sen- egalensis (Pers.) Bacle ex DC.

$=$ Crotalaria [unranked] Trifoliolatae Baker in Hooker, Fl. Brit.

India 2: 81.1879 - Type (designated here): C. trifolias- trum Willd.

= Crotalaria [unranked] Dispermae Baker in Hooker, Fl. Brit. India 2: 81. 1876 - Type (designated here): $C$. medicaginea Lam. 
$=$ Crotalaria sect. Erectae Wight \& Arn., Prodr. Fl. Ind. Orient. 1: $186.1834 \equiv$ C. ser. Erectae (Wight \& Arn.) Taub. in Engler \& Prantl, Nat. Pflanzenfam. 3(3): 228. 1893 - Type (designated here): C. formosa Wight \& Arn.

= Crotalaria sect. Dispermae Wight \& Arn. in Prodr. Fl. Ind. Orient. 1: 191. $1834 \equiv C$. ser. Dispermae (Wight \& Arn.) Taub. in Engler \& Prantl, Nat. Pflanzenfam. 3(3): 229. 1893 Type (designated here): $C$. rigida $\mathrm{B}$. Heyne ex Roth.

= Crotalaria [unranked] Fruticosae Benth. in London J. Bot. 2: $591.1843 \equiv$ C. ser. Fruticosae (Benth.) Taub. in Engler \& Prantl, Nat. Pflanzenfam. 3(3): 229. 1893 - Type (designated here): $C$. lotifolia $\mathrm{L}$.

= Crotalaria sect. Spinosae Baker f. in J. Linn. Soc., Bot. 42: 310. 1914 - Type: C. spinosa Hochst. ex Benth.

Crotalaria sect. Crotalaria is here broadened to in- clude C. sect. Dispermae and some species previously included in $C$. sect. Hedriocarpae (Axillariflora, Camptosepala, Crota- laria, Dispermae and Longirostres clades, Fig. 3).

7. Crotalaria sect. Stipulosae (Baker f.) M.M. le Roux \& B.-E. van Wyk, stat. nov. $\equiv C$. [unranked] Stipulaceae Benth. in London J. Bot. 2: 588. $1843 \equiv$ C. ser. Stipulaceae (Benth.) Taub. in Engler \& Prantl, Nat. Pflanzenfam. 3(3): 229. 1893, syn. nov. $\equiv C$. subsect. Stipulosae Baker f. in J. Linn. Soc., Bot. 42: 403. 1914 - Type (designated by Polhill, 1968) for C. subsect. Stipulosae Baker f.; designated here for C. [unranked] Stipulaceae Benth.: C. goreensis Guill. \& Perr.

Crotalaria subsect. Stipulosae is raised to sectional level and the circumscription remains the same as described by Pol- hill (1982).

8. Crotalaria sect. Glaucae (Benth.) M.M. le Roux \& B.-E. van Wyk, stat. nov. $\equiv$ C. [unranked] Glaucae Benth. in London J. Bot. 2: 479. $1843 \equiv$ C. ser. Glaucae (Benth.) Taub. in Engler \& Prantl, Nat. Pflanzenfam. 3(3): 228. 1893, pro parte $\equiv$ C. subsect. Glaucae (Benth.) Polhill in Kew Bull. 22: 230. 1968 - Type: C. glauca Willd.

= Crotalaria sect. Tetralobocalyx Harms in Bot. Jahrb. Syst. 54: 383. $1917 \equiv C$. subsect. Tetralobocalyx (Harms) Bisby \& Polhill in New Phytol. 72: 741. 1973, syn. nov. Type: $C$. nigricans Baker.

The circumscription of this section is slightly broadened to include not only $C$. subsect. Glaucae (Benth.) Polhill but also the monotypic C. subsect. Tetralobocalyx (Harms) Bisby \& Polhill (the latter characterised by a four-lobed calyx). In the molecular phylogeny, $C$. nigricans is shown to be embedded within $C$. sect. Glaucae.

9. Crotalaria sect. Geniculatae Polhill in Kew Bull. 22: 294. $1968 \equiv$ C. [unranked] Sphaerocarpae Benth. in London J. Bot. 2: 579. 1843, non C. sect. Sphaerocarpae Wight \& Arn. $1834 \equiv C$. sect. Sphaerocarpae (Benth.) Baker f. in J. Linn. Soc. Bot. 42: 273. 1914, nom. illeg., non Wight \& Arn. 1834 - Type: C. sphaerocarpa Perr. ex DC. 
The circumscription of this section (Polhill 1968, 1982) is slightly narrowed to exclude species with ridge callosities (e.g., C. bongensis and C. microcarpa) that form part of $C$. sect. Hedriocarpae and three species with thin-walled fruits that are restricted to North-East

Tropical Africa and Arabia, now included in C. sect. Borealigeniculatae.

10. Crotalaria sect. Amphitrichae M.M. le Roux \& B.-E. van Wyk in Syst. Bot. 38: 645. 2013 Type: C. colorata Schinz

= Crotalaria [unranked] Oliganthae Benth. in London J. Bot. 2: 573. $1843 \equiv C$. subsect. Oliganthae (Benth.) Bakerf. in J. Linn. Soc., Bot. 42: 386. 1914 - Type (designated here): $C$. humilis Eckl. \& Zeyh.

A group of seven species (C. colorata, C. excisa, C. hu- milis, C. meyerana, C. pearsonii and two new species) with a unique combination of floral characters, of which the am- phistylar hairs is the most useful (trichomes entirely surround the apical part of the style). This character is found elsewhere only in C. monophylla (C. sect. Geniculatae). The new section is the only one with a restricted distribution, limited to the west coast of South Africa and southern Namibia.

11. Crotalaria sect. Grandiflorae (Baker f.) Polhill in Kew Bull. 22: 201. $1968 \equiv C$. subsect. Grandiflorae Baker f. in J. Linn. Soc., Bot. 42: 314. 1914 - Type: Crotalaria laburnifolia $\mathrm{L}$.

= Clavulium Desv. in Ann. Sci. Nat. (Paris) 9: 407. $1826 \equiv$ Crotalaria subg. Clavulium (Desv.) Meisn., Pl. Vasc. Gen.: Tab. Diagn. 82, Commentarius 58. 1837 - Type: Clavulium pedunculosum (Desv.) Desv. (三 Crotalaria pedunculosa Desv.).

This section remains the same as circumscribed by Polhill $(1968,1982)$.

\section{Acknowledgements}

The following people and institutions are gratefully acknowl- edged: the National Research Foundation and the University of Johannesburg for financial support; the staff of CEN, ICN, JRAU, K, L, MEL, MO, NBG, P, SI, UPS and WIND for organizing herbarium loans and DNA samples; Dr. G. Koorsen (University of Johannesburg) for translating the diagnosis into Latin; Dr. J. Iganci (Federal Uni- versity of Rio Grande do Sul) for obtaining literature, Dr. A. Magee (SANBI) for help with molecular analyses; the Barcode of Life Data Systems and Guelph University for DNA sequencing (of the barcoding gene regions, matK and rbcLa); staff of the Jodrell Laboratory at Kew for DNA extractions and the staff of the Molecular and Systematics Laboratory at the University of Johannesburg for the use of facilities and technical support. 


\section{Literature cited}

Ansari, A.A. 2006. Taxonomic studies on the genus Crotalaria L. in India - II: Infrageneric classification. J. Econ. Taxon. Bot. 30: 570-582.

Ansari, A.A. 2008. Crotalaria L. in India. Dehra-Dunn: Bishen Singh

Mahendra Pal Singh.

Bain, J.F. \& Jansen, R.K. 2006. A chloroplast DNA hairpin structure

provides useful phylogenetic data within tribe Senecioneae (Aster- aceae). Canad. J. Bot. 84: 862-868. http://dx.doi.org/10.1139/bo6-057

Baker, E.G. 1914. The African species of Crotalaria. J. Linn. Soc., Bot. 42: 241-425.

Baker, J.G. 1876. Crotalaria. Pp. 65-85 in: Hooker, J.D. (ed.), Flora of British India, vol. 2. London: Reeve \& Co.

Bentham, G. 1843. Enumeration of the Leguminosae indigenous to southern Asia and central and southern Africa XV. Crotalaria. London J. Bot. 2: 472-481, 559-593.

Bisby, F.A. 1970. The evaluation and selection of characters in angio- sperm taxonomy: An example from Crotalaria. New Phytol. 69: 1149-1160. http://dx.doi.org/10.1111/j.14698137.1970.tb02495.X

Bisby, F.A. 1973. The role of taximetrics in angiosperm taxonomy I. Empirical comparisons of methods using Crotalaria L. New Phytol. 72: 699-726.

http://dx.doi.org/10.1111/j.1469-8137.1973.tbo4420.x

Bisby, F.A. \& Polhill, R.M. 1973. The role of taximetrics in angio- sperm taxonomy II. Parallel taximetric and orthodox studies in Crotalaria L. New Phytol. 72: 727-742. http://dx.doi.org/10.1111/j.1469-8137.1973.tbo4421.x

Boatwright, J.S., Le Roux, M.M., Wink, M., Morozova, T. \& Van Wyk, B.-E. 2008a. Phylogenetic relationships of tribe Crotalarieae (Fabaceae) inferred from DNA $\begin{array}{lllll}\text { sequences and } & \text { Borphology. } & \text { 33: }\end{array}$ http://dx.doi.org/10.1600/036364408786500271

Boatwright, J.S., Savolainen, V., Van Wyk, B.-E., Schutte-Vlok, A.L., Forest, F. \& Van der Bank, M. 2008b. Systematic posi- tion of the anomalous genus Cadia and the phylogeny of the tribe Podalyrieae (Fabaceae). Syst. Bot. 33: 133-147. http://dx.doi.org/10.1600/036364408783887500

Boatwright, J.S., Wink, M. \& Van Wyk, B.-E. 2011. The generic concept of Lotononis (Crotalarieae, Fabaceae): Reinstatement of the genera Euchlora, Leobordea and Listia and the new genus Ezoloba. Taxon 60: 161-177.

Cowan, R.S. 1959. Leguminosae of the western hemisphere. Taxon 8: 58-60. http://dx.doi.org/10.2307/1216031

Downie, S.R. \& Katz-Downie, D.S. 1996. A molecular phylogeny of Apiaceae subfamily Apioideae: Evidence from nuclear ribo- somal DNA internal transcribed spacer sequences. Amer. J. Bot. 83: 234-251. http://dx.doi.org/10.2307/2445943

Doyle, J.J. \& Doyle, J.L. 1987. A rapid DNA isolation procedure for small quantities of fresh leaf tissue. Phytochem. Bull. 19: 11-15.

Edwards, D., Horn, A., Taylor, D., Savolainen, V. \& Hawkins, J.A. 2008. DNA barcoding of a large genus, Aspalathus L. (Fabaceae).

Taxon 57: 1317-1327. 
Farris, J.S., Källersjö, M., Kluge, A.G. \& Bult, C. 1995. Testing significance of incongruence. Cladistics 10: 315-319. http://dx.doi.org/10.1111/j.1096-0031.1994.tbo0181.x

Felsenstein, J. 1985. Confidence limits on phylogenies: An approach using the bootstrap. Evolution 39: 783-791. http://dx.doi.org/10.2307/2408678

Fitch, W.M. 1971. Towards defining the course of evolution: Minimum change for a specified tree topology. Syst. Zool. 20: 406-416. http://dx.doi.org/10.2307/2412116

Flores, A.S., Corrêa, A.M., Forni-Martins, E.R. \& Tozzi, A.M.G.A.

2006. Chromosome numbers in Brazilian species of Crotalaria (Leguminosae, Papilionoideae) and their taxonomic significance. Bot. J. Linn. Soc. 151: 271-277.

http://dx.doi.org/10.1111/j.1095-8339.2006.00479.x

Harvey, W.H. 1862. Leguminosae. Pp. 39-47 in: Harvey, W.H. \& Sonder, O.W. (eds.), Flora capensis, vol. 2. Dublin: Hodges, Smith \& Co.

Hepper, F.N. 1958. Papilionaceae, Crotalaria. Pp. 544-553 in: Keay, R.W.J. (ed.), Flora of west tropical Africa. London: Crown Agents.

Huelsenbeck, J.P. \& Ronquist, F. 2001. MRBAYES: Bayesian infer- ence of phylogeny. Bioinformatics 17: 754-755. http://dx.doi.org/10.1093/bioinformatics/17.8.754

Jianqiang, L., Sun, H., Polhill, R.M. \& Gilbert, M.G. 2010. Crotalarieae: Crotalaria. Pp. 105-117 in: Wu, Z.Y., Raven, P.H. \& Hong, D.Y. (eds.), Flora of China, vol. 10. Beijing: Science Press; St. Louis: Missouri Botanical Garden Press.

Kress, W.J. \& Erickson, D.L. 2007. A two-locus global DNA barcode for land plants: The coding $r b c L$ gene complements the non-coding $p s b A-t r n H$ spacer region. PLoS One 2: e508. http://dx.doi.org/10.1371/journal.pone.0000508

Kress, W.J., Erickson, D.L., Jones, F.A., Swenson, N.G., Perez, R., Sanjur, O. \& Bermingham, E. 2009. Plant DNA barcodes and a community phylogeny of a tropical forest dynamics plot in Panama. Proc. Natl. Acad. Sci. U.S.A. 106: 18621-18626.

http://dx.doi.org/10.1073/pnas.090982010 6

Lahaye, R., Van der Bank, M., Bogarin, D., Warner, J., Pupulin, F., Gigot, G., Maurin, O., Duthoit, S., Barraclough, T.G. \& Savolainen, V. 2008. DNA barcoding the floras of biodiversity hotspots. Proc. Natl. Acad. Sci. U.S.A. 105: 2923-2928. http://dx.doi.org/10.1073/pnas.0709936105

Le Roux, M.M. 2011. A taxonomic study of the genus Crotalaria L. (Fa- baceae, tribe Crotalarieae) and a modified infrageneric classifica- tion system. Ph.D. thesis, University of Johannesburg, South Africa.

Le Roux, M.M. \& Van Wyk, B.-E. 2012. The systematic value of flower structure in Crotalaria and related genera of the tribe Cro- talarieae (Fabaceae). Flora 207: 414-426. http://dx.doi.org/10.1016/j.flora.2012.02.005

Le Roux, M.M. \& Van Wyk, B.-E. 2013. A taxonomic revision of Amphitrichae, a new section of Crotalaria (Fabaceae). Syst. Bot. 38: 638-652. http://dx.doi.org/10.160o/036364413X670296

Le Roux, M.M., Van Wyk, B.-E., Boatwright, J.S. \& Tilney, P.M.

2011. The systematic significance of morphological and anatomi- cal variation in fruits of Crotalaria and related genera of tribe Crotalarieae (Fabaceae). Bot. J. Linn. Soc. 165: 84106. http://dx.doi.org/10.1111/j.1095-8339.2010.01098.x 
Milne-Redhead, E. 1961. Miscellaneous notes on African species of Crotalaria L. Kew Bull. 15: 157-167. http://dx.doi.org/10.2307/4115786

Pandey, A., Singh, R., Sharma, S.K. \& Bhandari, D.C. 2010. Diversity assessment of useful Crotalaria species in India for plant genetic resources management. Genet. Resources Crop Evol. 57: 461-470. http://dx.doi.org/10.1007/s10722-009-9517-0

Polhill, R.M. 1968. Miscellaneous notes on African species of Crota- laria L. II. Kew Bull. 22: 169-348. http://dx.doi.org/10.2307/4107767 Polhill, R.M. 1976. Genisteae (Adans.) Benth. and related tribes (Le-guminosae). Bot. Syst. 1: 143-368.

Polhill, R.M. 1982. Crotalaria in Africa and Madagascar. Rotterdam: A.A. Balkema.

Posada, D. \& Crandall, K.A. 1998. Modeltest: Testing the model of DNA substitution. Bioinformatics 13: 817-818. http://dx.doi.org/10.1093/bioinformatics/14.9.817

Rambaut \& Drummond. 2009. Tracer. http://tree.bio.ed.ac.uk/down load.html? name $=$ tracer\&version $=$ v1.5\&id $=80 \&$ num $=2$

Ratnasingham, S. \& Hebert, P.D.N. 2007. BOLD: The Barcode of Life Data System (www.barcodinglife.org). Molec. Ecol. Notes 7: 355-364. http://dx.doi.org/10.1111/j.14718286.2007.01678.x

Reeves, G., Chase, M.W., Goldblatt, P., Fay, M.F., Cox, A.V., Lejeune, B. \& Souza-Chies, T. 2001. Molecular systematics of Iridaceae: Evidence from four plastid DNA regions. Amer. J. Bot. 88: 2074-2087. http://dx.doi.org/10.2307/3558433

Ronquist, F. \& Huelsenbeck, J.P. 2003. MRBAYES 3: Bayesian phylogenetic inference under mixed models. Bioinformatics 19: 1572-1574. http://dx.doi.org/10.1093/bioinformatics/btg180

Sang, T., Crawford, D.J. \& Stuessy, T.F. 1997. Chloroplast DNA phylogeny, reticulate evolution, and biogeography of Paeonia (Paeoniaceae). Amer. J. Bot. 84: 1120-1136. http://dx.doi.org/10.2307/2446155

Schreiber, A. 1970. Fabaceae. Pp. 16-28 in: Merxmüller, H. (ed.), Prodromus einer Flora von Südwestafrika, Lfg. 6o. Lehre: J. Cramer.

Seelanan, T., Schnabel, A. \& Wendel, J.F. 1997. Congruence and consensus in the cotton tribe (Malvaceae). Syst. Bot. 22: 259-290. http://dx.doi.org/10.2307/2419457

Sun, Y., Skinner, D.Z., Liang, G.H. \& Hulbert, S.H. 1994. Phylo- genetic analysis of sorghum and related taxa using internal tran- scribed spacers of nuclear ribosomal DNA. Theor. Appl. Genet. 89: 26-32. http://dx.doi.org/10.1007/BFo0226978

Swofford, D.L. 2002. PAUP*: Phylogenetic analysis using parsimony (*and other methods). Sunderland, Massachusetts: Sinauer.

Tamura, K., Dudley, J., Nei, M. \& Kumar, S. 2007. MEGA4: Mo- lecular evolutionary genetics analysis (MEGA) software version 4.0. Molec. Biol. Evol. 24: 1596-1599. http://dx.doi.org/10.1093/molbev/msmo92

Thulin M. 1991. Two new species of Crotalaria (Leguminosae) from Somalia. Nordic J. Bot. 11: 97-101. http://dx.doi.org/10.1111/j.1756-1051.1991.tbo1804.x

Torre, A.R. 1962. Crotalaria. Pp. 6-76 in: Exell, A.W. \& Fernandes, A. (eds.), Conspectus Florae Angolensis, vol. 3. Lisboa: Junta de Investigações do Ultramar.

Van Wyk, B.-E. 1991. A review of the tribe Crotalarieae (Fabaceae). Contr. Bolus Herb. 13: 265-288. http://dx.doi.org/10.1016/So305-1978(03)0oo83-8

\section{http://repository.uwc.ac.za}


Van Wyk, B.-E. 2003. The value of chemosystematics in clarifying relationships in the genistoid tribes of papilionoid legumes. Bio- chem. Syst. Ecol. 31: 875-884.

Van Wyk, B.-E. 2005. Tribe Crotalarieae. Pp. 273-281 in: Lewis, G., Schrire, B., Mackinder, B. \& Lock, M. (eds.), Legumes of the World. Kew: Royal Botanic Gardens.

Van Wyk, B.-E. \& Schutte, A.L. 1989. Taxonomic relationships amongst some genera of Leguminosae tribe Crotalarieae and Argyrolobium (Genisteae). Kew Bull. 44: 397-423. http://dx.doi.org/10.2307/4110360

Van Wyk, B.-E. \& Schutte, A.L. 1995. Phylogenetic relationships in the tribes Podalyrieae, Liparieae and Crotalarieae. Pp. 283-308 in: Crisp, M. \& Doyle, J. (eds.), Advances in legume systematics, vol. 7. Kew: Royal Botanic Gardens.

Van Wyk, B.-E. \& Verdoorn, G. 1990. Alkaloids as taxonomic characters in the tribe Crotalarieae (Fabaceae). Biochem. Syst. Ecol. 18: 503-515. http://dx.doi.org/10.1016/03051978(90)90122-V

Van Wyk, B.-E., Venter, M. \& Boatwright, J.S. 2010. A revision of the genus Bolusia (Fabaceae, Crotalarieae). S. African J. Bot. 76: 86-94. http://dx.doi.org/10.1016/j.sajb.2009.08.010

Verdoorn, I.C. 1928. A revision of the Crotalarias of South and South- East Tropical Africa. Bothalia 2: 371-420.

Werle, E., Schneider, C., Renner, M., Volker, M. \& Fiehnet, W. 1994. Convenient single-step, one tube purification of PCR products for direct sequencing. Nucl. Acids Res. 22: 4354-4355. http://dx.doi.org/10.1093/nar/22.20.4354

White, T.J., Bruns, T., Lee, S. \& Taylor, J. 1990. Amplification and direct sequencing of fungal ribosomal RNA genes for phylogenet- ics. Pp. 315-322 in: Innis, M.A., Gelfand, M.A., Sninsky, J.J. \& White, T.J. (eds.), PCR protocols. New York: Academic Press.

Whitlock, B.A., Hale, A.M. \& Groff, P.A. 2010. Intraspecific inver- sions pose a challenge for the trnH-psbA plant DNA barcode. PLoS ONE 5: e11533. http://dx.doi.org/10.1371/journal.pone.0011533

Wight, R. \& Walker-Arnott, G.A. 1834. Prodromus florae peninsula Indiae orientalis. London: Parburry, Allen \& Co.

Wilczek, R. 1953a. Papilionaceae Genisteae Congolanae Novae (Robyn- siophyton, Crotalaria, Argyrolobium). Bull. Jard. Bot. État Brux- elles 23: 125-211.

Wilczek, R. 1953b. Crotalaria. Pp. 43-273 in: Robyns, W., Staner, P., Demaret, F., Germain, R., Gilbert, G., Hauman, L., Homès, M., Jurion, F., Lebrun, J., Van den Abeele, M. \& Boutique, R. (eds.), Flore du Congo Belge, vol. 4. Brussels: Institut National pour l'Étude Agronomique du Congo belge.

Yoder, A.D., Irwin, J.A. \& Payseur, B.A. 2001. Failure of the ILD to determine data combinability for slow loris phylogeny. Syst. Biol. 50: 408-424.

http://dx.doi.org/10.1080/106351501300318003 